\title{
Infection by Amoebophrya spp. parasitoids of dinoflagellates in a tropical marine coastal area
}

\author{
Paulo S. Salomon ${ }^{1, *}$, Edna Granélii ${ }^{1}$, Maria H. C. B. Neves ${ }^{2}$, Eliane G. Rodriguez ${ }^{2}$ \\ ${ }^{1}$ Marine Sciences Centre, University of Kalmar, 39182 Kalmar, Sweden \\ ${ }^{2}$ Instituto de Estudos do Mar Almirante Paulo Moreira, Rua Kioto 253, 28930-000 Arraial do Cabo, Rio de Janeiro, Brazil
}

\begin{abstract}
Infection of marine dinoflagellates by the parasitic dinoflagellate Amoebophrya spp. plays an important role in population dynamics and carbon flow in marine food webs. It has been extensively reported that Amoebophrya parasitoids occur in temperate coastal areas of the northern hemisphere; however, little is known about their distribution and importance in tropical areas and southern oceans. We used an rRNA-based, fluorescent in situ hybridization assay to detect Amoebophrya spp. infections during the decline of a late-summer dinoflagellate population dominated by Ceratium falcatiforme in a tropical coastal area of the southern Atlantic Ocean subjected to recurrent upwelling-downwelling cycles. Conditions during our survey were typical of downwelling when oligotrophic waters dominate the area. C. falcatiforme was the most infected host, with a prevalence averaging $2 \%$ over the study area at the beginning of sampling. At a fixed sampling station monitored over $4 \mathrm{wk}$, Amoebophrya prevalence escalated from 1 to $7 \%$ over a $6 \mathrm{~d}$ period, concomitant to a $94 \%$ decrease in host cell numbers. Infection by Amoebophrya was estimated to have killed ca. $11 \%$ of the host cell population within this period; thus, parasitism was not the main factor behind the C. falcatiforme population decline. Estimates based on biovolume calculations indicate that ca. $6.5 \%$ of the carbon in the decaying C. falcatiforme population was transformed into parasitoid dinospores, which became available to tintinnid ciliates that were abundant during our survey. Such a trophic link might be relevant in tropical oligotrophic waters when the system is characterized by a microbial food web structure.
\end{abstract}

KEY WORDS: Amoebophrya spp. C Ceratium falcatiforme · Parasitism · Dinoflagellates · FISH probes · South Brazil Bight

\section{INTRODUCTION}

Parasitism is a widespread inter-specific interaction in both terrestrial and aquatic habitats (Combes 2001). Heterotrophic dinoflagellates belonging to the genus Amoebophrya are remarkable, as they are able to infect not only several metazoans but also protists (Cachon \& Cachon 1987). One such parasite, originally described as a single species, Amoebophrya ceratii Koepen, but currently recognized as a species complex (Coats et al. 1996, Coats \& Park 2002, Gunderson et al. 2002, Salomon et al. 2003a, Kim et al. 2004, 2008), infects marine dinoflagellates. More than 40 marine dinoflagellate species from ca. 20 different genera are susceptible to Amoebophrya spp. (Park et al. 2004).
The life cycle of Amoebophrya spp. displays 2 distinct phases: a free-swimming phase represented by small, flagellated forms called dinospores, and a parasitic, trophic phase whereby dinospores develop inside the host cells from which they derive their food (Cachon 1964, Cachon \& Cachon 1987). Although aspects of the biology of free-living dinospores are known from cultured dinoflagellate-Amoebophrya systems (Coats \& Park 2002), abundance and diversity of these freeliving stages in natural marine waters have only recently been reported on with the help of molecular techniques (Chambouvet et al. 2008).

Infections of dinoflagellates by Amoebophrya spp. are lethal (Cachon 1964, Coats \& Bockstahler 1994), rendering Amoebophrya spp. a typical parasitoid fea- 
ture. Therefore, for host-population dynamics, parasitism by Amoebophrya spp. is similar to predation by grazers, in that part of the host population will be killed.

Studies on cultured host-parasitoid systems have revealed important features of Amoebophrya spp. infection dynamics and interaction with their hosts at the cellular level (Coats \& Bockstahler 1994, Park et al. 2002). For Amoebophrya-host systems that are not established in cultures, the biology of the interaction is best studied by direct observation of natural host populations. Field studies offer an opportunity to assess the host range and prevalence (i.e. the percentage of infected cells in the host population) of Amoebophrya spp. in the presence of several potential host species and other components of the microbial community that can interfere with the process. In this respect, molecular probes targeting ribosomal RNA (rRNA) have been successfully used to detect infection by morphologically similar but genetically distinct Amoebophrya spp. on natural dinoflagellate populations, helping to clarify the parasitoid's diversity and several host-specificity issues (Salomon et al. 2003a, Chambouvet et al. 2008).

The frequency of high Amoebophrya spp. prevalence events in nature seems to be different among different Amoebophrya-dinoflagellate systems. For example, infection of the dinoflagellate Dinophysis norvegica in the Baltic Sea is seldom above $10 \%$ (Gisselson et al. 2002, Salomon et al. 2003b, 2006a), whereas Gyrodinium uncatenum and Scrippsiella trochoidea populations in Chesapeake Bay frequently show localized, high-prevalence levels up to $80 \%$ (Coats et al. 1996). High virulence and the narrow host ranges of several Amoebophrya spp. observed both in laboratory and field studies support the idea that these parasitoids can contribute to the decline of a host population, making them potential candidates as mitigating agents against harmful dinoflagellate blooms (Coats \& Park 2002, Chambouvet et al. 2008). Moreover, highly host-specific parasites influence phytoplankton community structure and species succession (Ibelings et al. 2004).

Infection of dinoflagellates by Amoebophrya can also alter the carbon flow within marine food webs. Dinospores released from dinoflagellate hosts at the end of the trophic phase can be ingested by ciliates (Maranda 2001, Johansson \& Coats 2002) creating new, temporary trophic links within the microbial food web.

Amoebophrya spp. occur in marine coastal areas worldwide, although most records come from temperate regions in the northern hemisphere (see the review by Park et al. 2004). Coastal tropical waters, on the other hand, have received little attention (Salomon et al. 2006b). In the present study, we used an rRNA- based probe assay to investigate dinoflagellate infection by Amoebophrya spp. during the decline of a latesummer dinoflagellate assemblage in the coastal waters off Cabo Frio, $150 \mathrm{~km}$ north of Rio de Janeiro, in the South Brazil Bight. This area is of particular interest due to recurrent upwelling events that influence marine food webs in this region (Valentin 1984).

\section{MATERIALS AND METHODS}

Sampling. Sampling was performed onboard the RV 'Diadorim' (IEAPM-Brazilian Navy), off the Rio de Janeiro State coast $\left(23^{\circ} 00^{\prime} \mathrm{S}, 42^{\circ} 00^{\prime} \mathrm{W}\right)$, in the Cabo Frio area, South Brazil Bight (Fig. 1). The first sample used to quantify parasitic infection of dinoflagellates was taken during routine monitoring in the area (Stn E; Fig. 1) on March 23, 2004, when several cells of Ceratium falcatiforme E. G. Jørgensen were observed to harbor Amoebophrya spp.-like trophonts. Afterwards, the plankton communities were collected on March 24 at 5 stations (Stns A to E; Fig. 1). Stns A, B, and C, depths between 26 and $57 \mathrm{~m}$, were located on an upwelling area. Stns D and E, 10 and $5 \mathrm{~m}$ deep, respectively, were located in a protected area inside Anjos Bay. In order to follow the development of the planktonic communities and infection by Amoebophrya spp., sampling continued for several weeks at Stn E (Fig. 1). Water temperature, salinity, and chlorophyll fluorescence depth profiles were measured using a conductivity, temperature, and depth profiler. Water was collected with a 21 Niskin bottle from the surface and from 1 intermediate depth (15 m at Stns A, B, and C; $5 \mathrm{~m}$ at

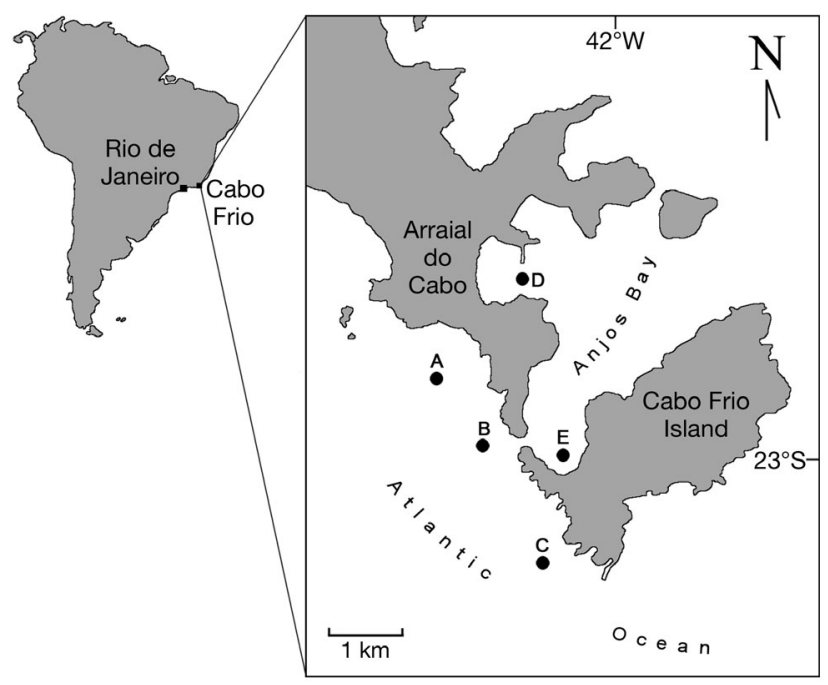

Fig. 1. Location of the 5 stations (A to E) sampled in the present study 
Stn D and $3 \mathrm{~m}$ at Stn E). Vertical net hauls (mesh size: $20 \mu \mathrm{m})$ were also taken on every occasion from nearbottom to surface (from $30 \mathrm{~m}$ to surface at Stn C).

Sample preservation. Aliquots of 0.51 of seawater were fixed with formalin ( $2 \%$ final concentration) for identification and quantification of planktonic cells. Net tow material was concentrated down to $7 \mathrm{ml}$ in 2 size fractions, 20 to $70 \mu \mathrm{m}$ and 70 to $300 \mu \mathrm{m}$, using nylon nets mounted on Plexiglas tubes. After fractionation, cells were fixed with $4 \%$ paraformaldehyde in phosphate-buffered saline (PBS, pH 8.0) for $1 \mathrm{~h}$, rinsed once with $\mathrm{PBS}$, twice with $70 \%(\mathrm{v} / \mathrm{v})$ ethanol, transferred to $70 \%$ ethanol and stored at $-20^{\circ} \mathrm{C}$ (Salomon et al. 2003a).

Cell counts. Identification and quantification of autoand heterotrophic dinoflagellates, other phytoplankton species, and tintinnid ciliates were carried out using the formalin-fixed samples. Cells were analyzed using an inverted microscope at 400× magnification following Utermöhl's (1958) sedimentation technique. Only the fraction $>20 \mu \mathrm{m}$ was analyzed.

Probe hybridization. Detection of Amoebophrya spp. inside host cells was done by fluorescent (whole cell) in situ hybridization (FISH) with a fluoresceintagged, rRNA-based oligonucleotide probe (5'-TTA TTA TGA (AG)TC ATC CAA AA-3'). The probe was designed based on 13 small subunit rDNA sequences of Amoebophrya spp. available in the GenBank database (www.ncbi.nlm.nih.gov; Accession Numbers: AF069516, AF239260, AF472553, AF472554, AF472555, AY208892, AY208893, AY208894, AY260467, AY260468, AY260469, AY775284, AY775285). These sequences are from Amoebophrya spp. that have been observed infecting the following dinoflagellates: Gymnodinium sanguineum (=Akashiwo sanguinea), Dinophysis norvegica, Karlodinium micrum, Gymnodinium instriatum, Scrippsiella sp., Ceratium tripos, Prorocentrum micans, Prorocentrum minimum, Ceratium lineatum, Alexandrium affine, and Gonyaulax polygramma. Hybridization of samples from various sea areas showed that the probe detects Amoebophrya in several different dinoflagellates species (P. S. Salomon et al. unpubl. data). Cells from the vertical net tows stored in $70 \%$ ethanol were used in the assays following Salomon et al. (2003a), except that hybridization was done overnight at $50^{\circ} \mathrm{C}$ instead for $5 \mathrm{~h}$ at $45^{\circ} \mathrm{C}$. After hybridization, cells were counter-stained for ca. $15 \mathrm{~min}$ with 0.5 to $1 \mu \mathrm{g} \mathrm{ml}^{-1}$ DAPI, resuspended in an antifade solution (SlowFade Antifade, Molecular Probes), and mounted on microscope slides with cover slips sealed with nail polisher. Detection was carried out with an Olympus BX40 epifluorescence microscope, with filter sets suitable for fluorescein $\left(\lambda_{\text {ex }} 470\right.$ to $490 \mathrm{~nm}, \lambda_{\text {em }}>550 \mathrm{~nm}$ ) and DAPI ( $\lambda_{\text {ex }} 360$ to $370 \mathrm{~nm}$, $\lambda_{\mathrm{em}}>420 \mathrm{~nm}$ ) absorption/emission spectra.
Amoebophrya infections. At least 2000 cells of Ceratium falcatiforme and 1000 cells of both Dinophysis acuminata and Prorocentrum minimum were analyzed and scored as infected or non-infected. Amoebophrya spp. prevalence was expressed as a percentage of infected cells. Infections were further discriminated according to parasitoid developmental stage as 'early' (prior to circular configuration of parasitoid nuclei) or 'late' stage (all other stages). Parasitoid prevalence in dinoflagellate species other than the ones mentioned above could not be precisely estimated due to low cell densities. However, in order to verify whether these or any other cells in the samples were also infected, 3 to 5 slides sample ${ }^{-1}$ were scanned for a probe signal without scoring cell numbers. Whenever a positive probe signal was detected, the host was identified and the parasitoid infection stage and location inside the host were determined.

To check the efficiency of the probe in detecting the Amoebophrya-infected dinoflagellates present in the samples, 1 slide from each sample was scanned for infection based on DAPI, which allows identification of middle to late infection stages based on hollow spaces in the host nucleus or the circular or multinucleated pattern of the parasitoids trophont nuclei, respectively. Cells found infected based on the DAPI signal were checked for a probe signal.

Cell measurements, biovolume, and carbon content estimates. Material from the net tow collected at Stn E on March 24 was hybridized with the probe as described above. To avoid possible distortion effects from the cover slip, cells were mounted in a $100 \mu \mathrm{m}$ deep chamber (Palmer Maloney) and analyzed at 200x magnification. Linear measurements of girdle diameter, total, hypothecal, and epithecal length were conducted in 20 uninfected Ceratium falcatiforme cells and in 20 cells infected with a mature trophont. Host biovolume was calculated using a double-cone geometrical approximation, whereas trophont biovolume was calculated as a prolate spheroid based on linear measurements of diameter and height (Hillebrand et al. 1999). Carbon contents were then estimated based on biovolume according to Menden-Deuer \& Lessard (2000).

\section{RESULTS}

\section{Oceanographic conditions}

Surface water temperature at all 5 sampling stations on March 24 was ca. $24^{\circ} \mathrm{C}$. Vertical temperature profiles indicated a homogeneous upper layer, with little temperature variation throughout the water column above $35 \mathrm{~m}$ depth. A well-defined thermocline was 
observed at Stn C, with a sharp gradient from 24 to $18.5^{\circ} \mathrm{C}$ between 35 and $45 \mathrm{~m}$ depth (Fig. 2). At Stn E, water temperature did not vary much over time, decreasing by only $1^{\circ} \mathrm{C}$ (from 24 to $23^{\circ} \mathrm{C}$ ) by the end of the 4 wk sampling period. Salinity at the surface was ca. 35.1 at Stns A to C, and slightly higher (ca. 35.2) at Stns D and E (Fig. 2). Depth profiles showed little variation in salinity, except at Stn C, where a layer of lower salinity water (ca. 31.5) was present at ca. $40 \mathrm{~m}$ depth. Salinity at Stn E remained at around 31.2 during the whole sampling period. Relative chlorophyll fluorescence was similar at the surface across the 5 sampling stations. At the 3 deepest sampling stations (Stns A, B, and $C_{i}$ see Fig. 1), chlorophyll fluorescence maxima were observed at ca. $15 \mathrm{~m}$ depth (Fig. 2).

\section{Composition of the plankton community}

Dinoflagellates dominated the plankton communities at all 5 locations on March 24, with cell densities reaching up to $7 \times 10^{3} \mathrm{l}^{-1}$ at $\mathrm{Stn} \mathrm{B}$. On average, dinoflagellate cells accounted for $88 \%$ of the planktonic organisms larger than $20 \mu \mathrm{m}$ (including auto- and heterotrophic dinoflagellates, other phytoplankton, and tintinnid ciliates). The most abundant species was Ceratium falcatiforme, with cell densities ranging from $1.3 \times 10^{3}$ cells $1^{-1}$ at Stn $C$ to $6.5 \times 10^{3}$ cells $1^{-1}$ at Stn B (Fig. 3a). Overall, C. falcatiforme cells represented 61 to $92 \%$ of the dinoflagellates and 49 to $88 \%$ of the plankton community's $(>20 \mu \mathrm{m})$ total cell numbers.
Two other dinoflagellate species, Dinophysis acuminata and Prorocentrum minimum, were present in all samples at densities of up to $0.3 \times 10^{3}$ and $0.7 \times 10^{3}$ cells $1^{-1}$, respectively. Other dinoflagellates present included C. furca, C. macroceros, C. tripos, Protoperidinium spp. and several unidentified peridinoid forms, but in very low densities. The diatom communities, represented mainly by the genera Chaetoceros, Coscinodiscus, Ditylum, Navicula, and Nitszchia, were present at maximum cell densities of ca. $0.5 \times 10^{3}$ cells $\mathrm{l}^{-1}$ (Fig. 3c). Tintinnid ciliates were observed in all samples at densities between 0.08 and $0.56 \times 10^{3}$ cells $\mathrm{l}^{-1}$ (Fig. 3d). In general, cell densities of C. falcatiforme and other groups were similar between surface and deep samples, typically with less than a 2-fold difference between them (Fig. 3). Exceptions were the dinoflagellate communities - not including C. falcatiforme-and tintinnids at Stn $\mathrm{E}$, where cell numbers were, respectively, 3.4 and 4.7 times higher at the surface than at $15 \mathrm{~m}$ depth (Fig. 3b,d).

A shift in dominance from dinoflagellates to diatoms occurred in the planktonic communities at Stn E during the 4 wk sampling (Fig. 4). Ceratium falcatiforme cell densities decreased by $94 \%$ - from $3.55 \times 10^{3}$ to $0.22 \times$ $10^{3}$ cells $1^{-1}$ - between March 24 and March 30. By April 20, C. falcatiforme densities had decreased to $0.06 \times 10^{3}$ cells $^{-1}$ at $3 \mathrm{~m}$ depth and were below detection limit at the surface. Cell numbers of dinoflagellate species other than C. falcatiforme showed a similar trend, though with a less pronounced decrease (Fig. 4c). As a result, C. falcatiforme became less repre-
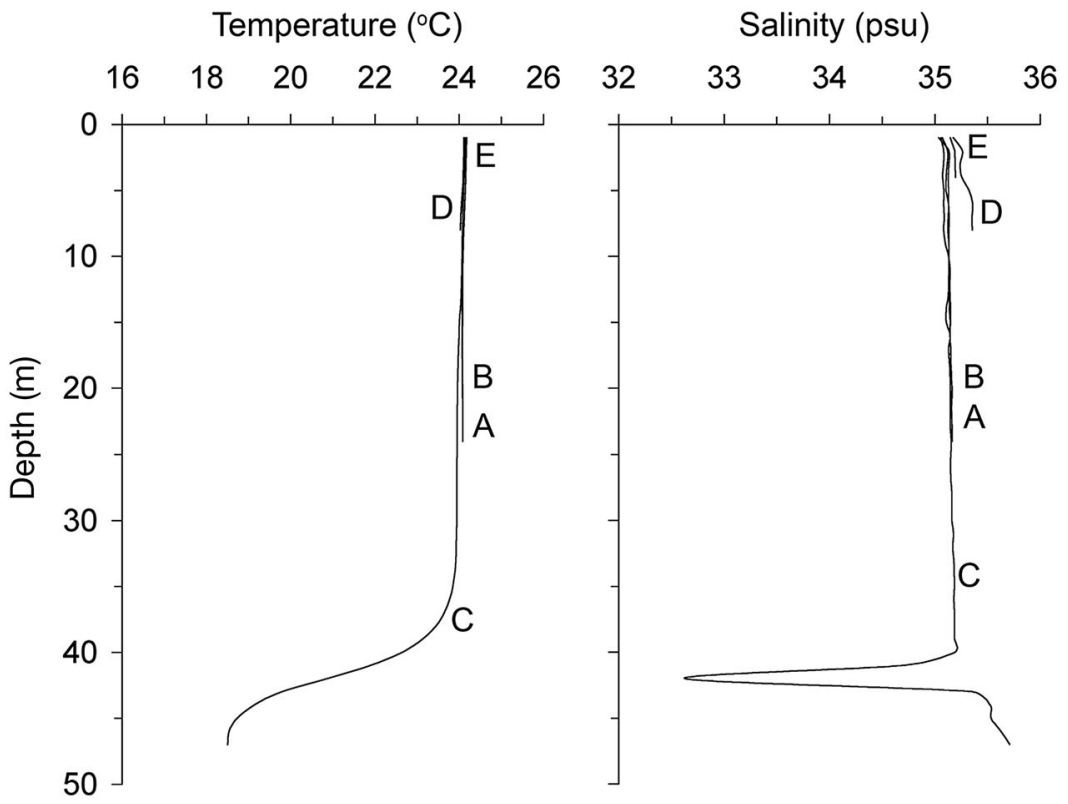

\section{Chlorophyll fluorescence (rel)}

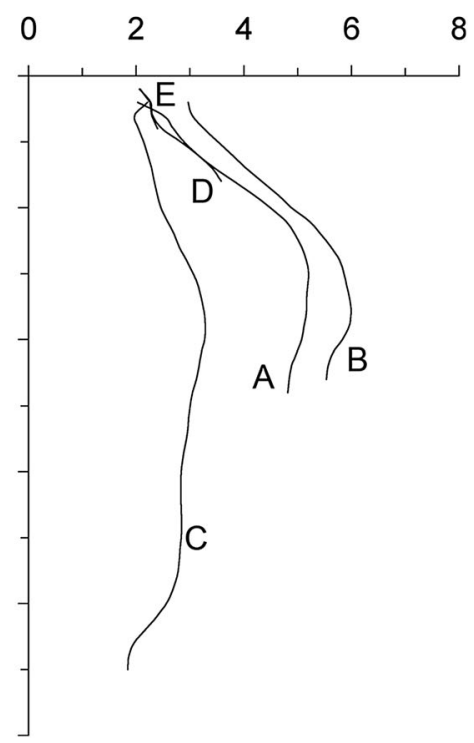

Fig. 2. Depth profiles of temperature, salinity and chlorophyll fluorescence (rel: relative units) at the 5 stations (A to E) in the Cabo Frio area shown in Fig. 1 

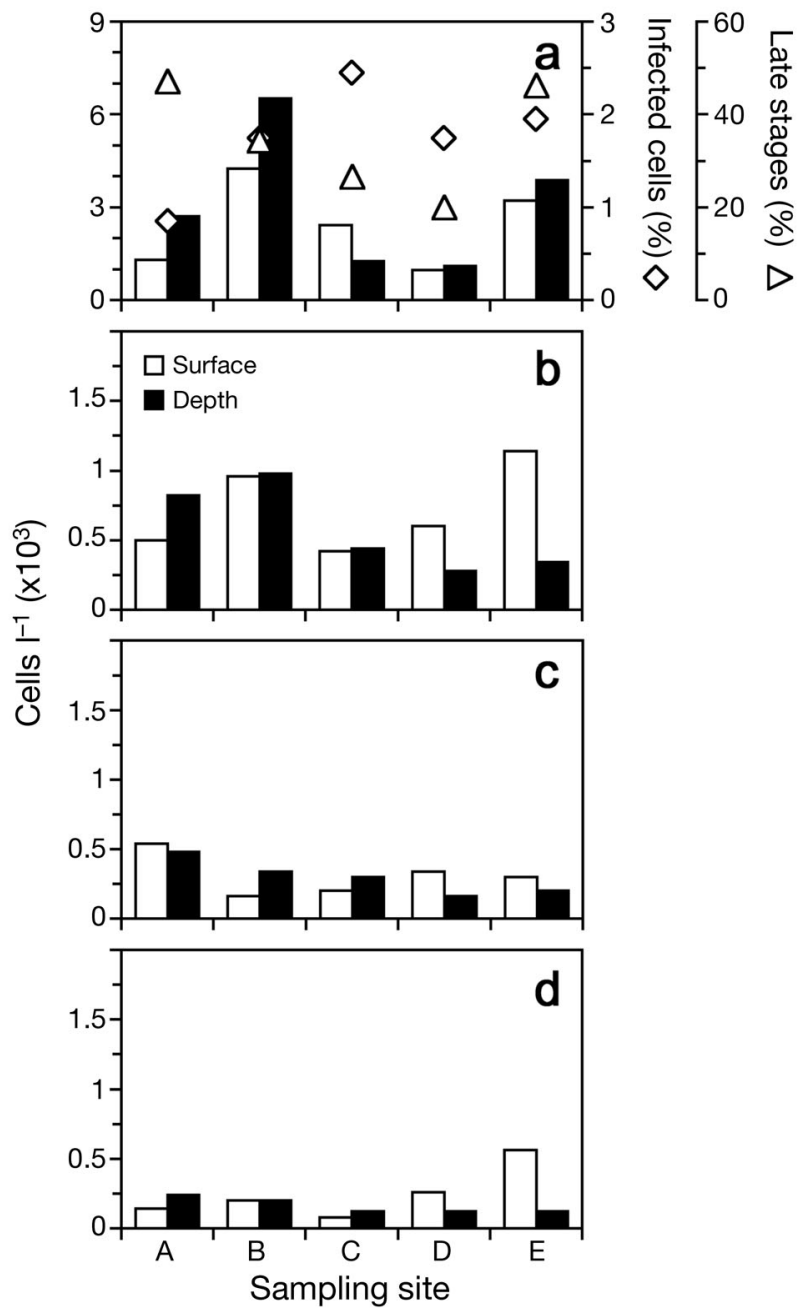

Fig. 3. Abundance of components of the plankton community and Amoebophrya spp. prevalence on Ceratium falcatiforme at the 5 stations (A to E). Cell densities are shown for surface and intermediate depth samples (see 'Materials and methods' for details). (a) Left $y$-axis: C. falcatiforme cell densities; right $y$-axis: parasite prevalence (percentage of infected cells) and percentage of late infection stages of the parasite relative to the total infected host cells. (b) Dinoflagellates other than

C. falcatiforme, (c) diatoms and (d) tintinnid ciliates

sentative among the dinoflagellates over the $4 \mathrm{wk}$ sampling period. On the 2 last sampling occasions, C. falcatiforme represented $<20 \%$ of the dinoflagellate cells in the samples. Moreover, increasing amounts of C. falcatiforme cells with low pigmentation, empty theca, as well as fragments of $C$. falcatiforme theca were found in the samples towards the end of the sampling period. Diatoms, on the other hand, were found at their highest numbers at the end of the sampling period $(2.4 \times$ $10^{3}$ cells $^{-1}$ ) at the surface, when they represented $90 \%$ of the plankton community (Fig. 4d). Tintinnids decreased in numbers to almost undetectable levels from April 4 and onward (Fig. 4e).
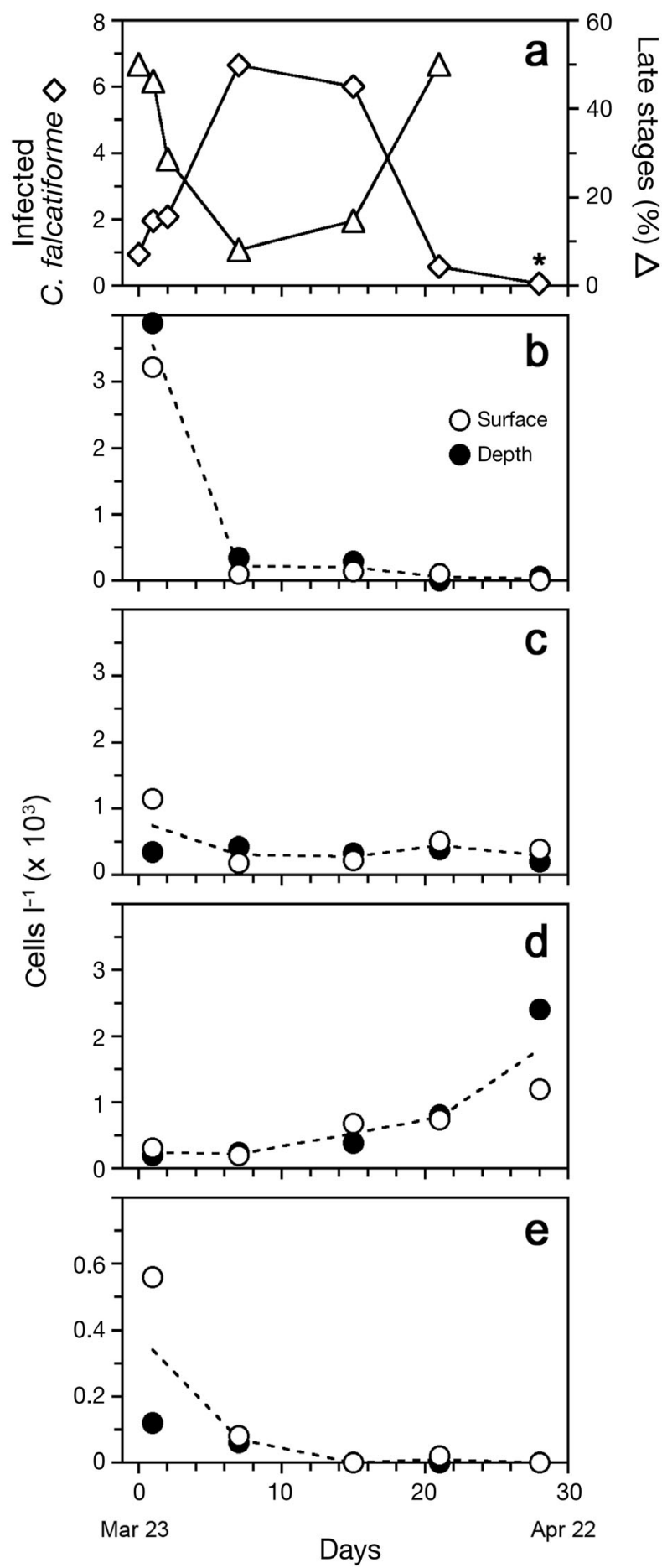

Fig. 4. Development of the plankton community and infection by Amoebophrya spp. of Ceratium falcatiforme at sampling Stn E over a 4 wk period. (a) Parasitoid prevalence and percentage of late infection stages relative to the total infected host cells $\left({ }^{*}\right.$ : estimate of percentage of late stages was not possible because prevalence was below detection limit, i.e. no infected cells out of 2000 cells analysed). (b) C. falcatiforme cell density, (c) other dinoflagellates, (d) diatoms and (e) tintinnid ciliates. Dashed line: average of surface and intermediate depth sample values 


\section{Amoebophrya infections}

Probe hybridization unveiled at least 9 dinoflagellate species infected by Amoebophrya spp. (Table 1). A positive probe signal was seen almost exclusively inside dinoflagellates, including the genera Ceratium, Prorocentrum, Protoperidinium, Dinophysis, and several non-identified peridinoid forms. To an overwhelming degree infections were found in the dominant dinoflagellate species, C. falcatiforme (Fig. 5). The only non-dinoflagellate cells with positive probe signals were from a tintinnid ciliate (Table 1). In some cases, the round bodies unveiled by the probe signal inside tintinnid cells were larger than the smallest forms found in dinoflagellate hosts (Fig. 6). Fully developed trophonts were never observed inside tintinnids. In dinoflagellates, probe signal showed the presence of a wide range of Amoebophrya development stages inside the host cells. The late developmental stage represented by mature trophonts appeared as a large, green mass occupying almost the whole host intracellular space (Fig. 5a-c). At this infection stage, host chloroplasts and the nucleus were no longer present. Instead, the multinucleated, pattern of the parasitoid syncytium was evident by the DAPI signal (Fig. 5c). The earliest infection stages were detected as small (ca. $5 \mu \mathrm{m}$ ) round bodies, both in the cytoplasm and in the nucleus of the host (Fig. 5d). In many cases, the exact infection in the host nucleus could be seen in the DAPI signal as an empty space matching in size and location the round bodies unveiled by the probe signal (Fig. 5f). All infected cells detected based on the DAPI signal had positive probe signals.
Prevalence of Amoebophrya spp. on Ceratium falcatiforme on March 23 averaged ca. 2\%. Maximum estimated prevalence was $2.5 \%$ at Stn C. Despite differences in prevalence levels among sites, no correlation was found between prevalence and host densities. Percentage of late infection stages ranged from $20 \%$ at sampling Stn D up to $50 \%$ at Stn A (Fig. 3a). The time course of infection measured at Stn E showed a 7-fold, nearly linear increase in parasitoid prevalence from 1 to $7 \%$ in $1 \mathrm{wk}$ (Fig. 4a). This increase in prevalence occurred simultaneously with the decline in the C. falcatiforme population. Parasitoid prevalence remained at ca. $6 \%$ for another week, but thereafter decreased to $<1 \%$, and then fell under the detection limit. The percentage of late infection stages showed an opposite trend compared to prevalence (Fig. 4a). Percentage of late stages decreased from 50 to $<10 \%$, while prevalence increased during the first week of sampling, and increased again to initial levels as prevalence decreased towards the end of the sampling period.

\section{Biovolume and carbon content}

Ceratium falcatiforme cells infected with mature Amoebophrya trophonts were on average $25 \%$ wider (mean girdle diameter $=25.4 \mu \mathrm{m}, \mathrm{CV}=8.1 \%$ ) than non-infected cells (mean girdle diameter $=20.3 \mu \mathrm{m}$, $\mathrm{CV}=7.8 \%$ ). Cell length was not significantly different between the 2 groups ( $t$-test: $p=0.8472)$. Average cell volume for uninfected $C$. falcatiforme was $22926 \mu^{3}$ $(\mathrm{CV}=17 \%)$, whereas cells infected with mature Amoebophrya spp. trophonts had an average biovolume of $36616 \mu^{3}(C V=21 \%)$. Carbon content based

Table 1. Infection of Amoebophrya spp. on dinoflagellates as detected by the FISH probe signal. Presence of infection (x) is shown for various host species at different locations (see Fig. 1) and on different dates. Observations of nuclear infections (o) are also given. Observations of the probe signal inside tintinnid ciliates are indicated in the last line

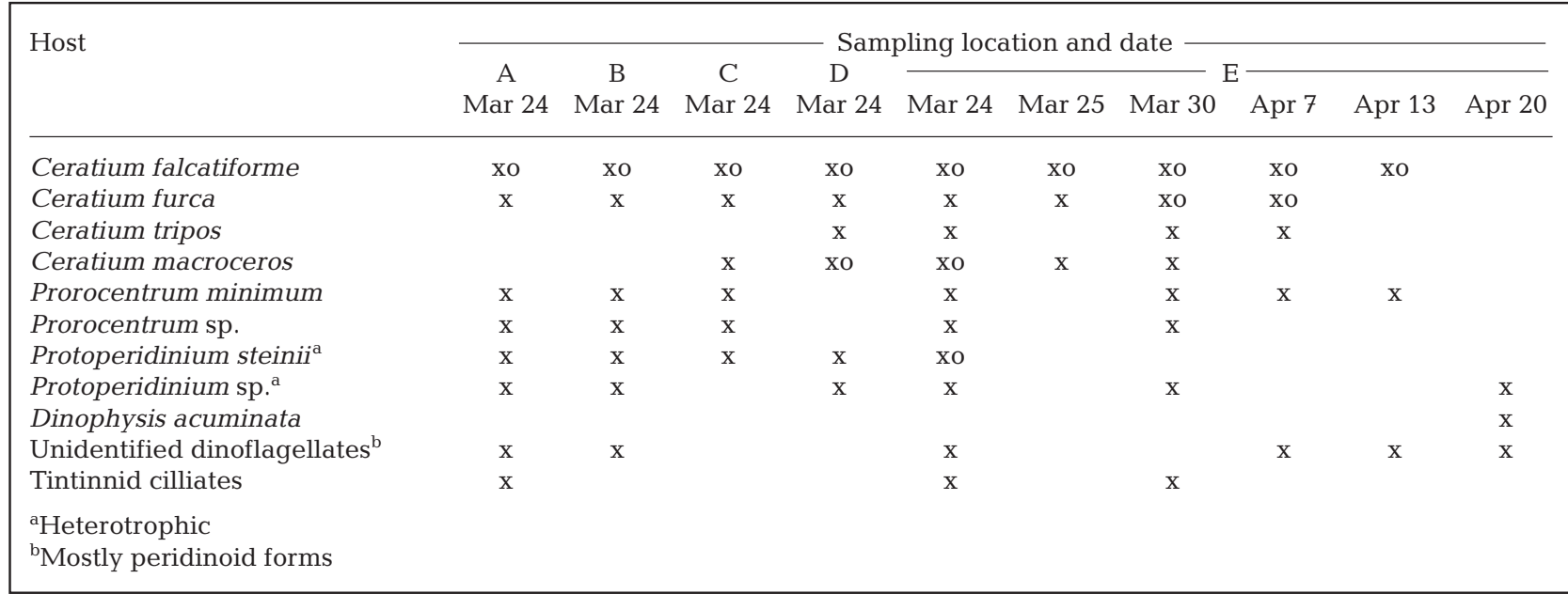




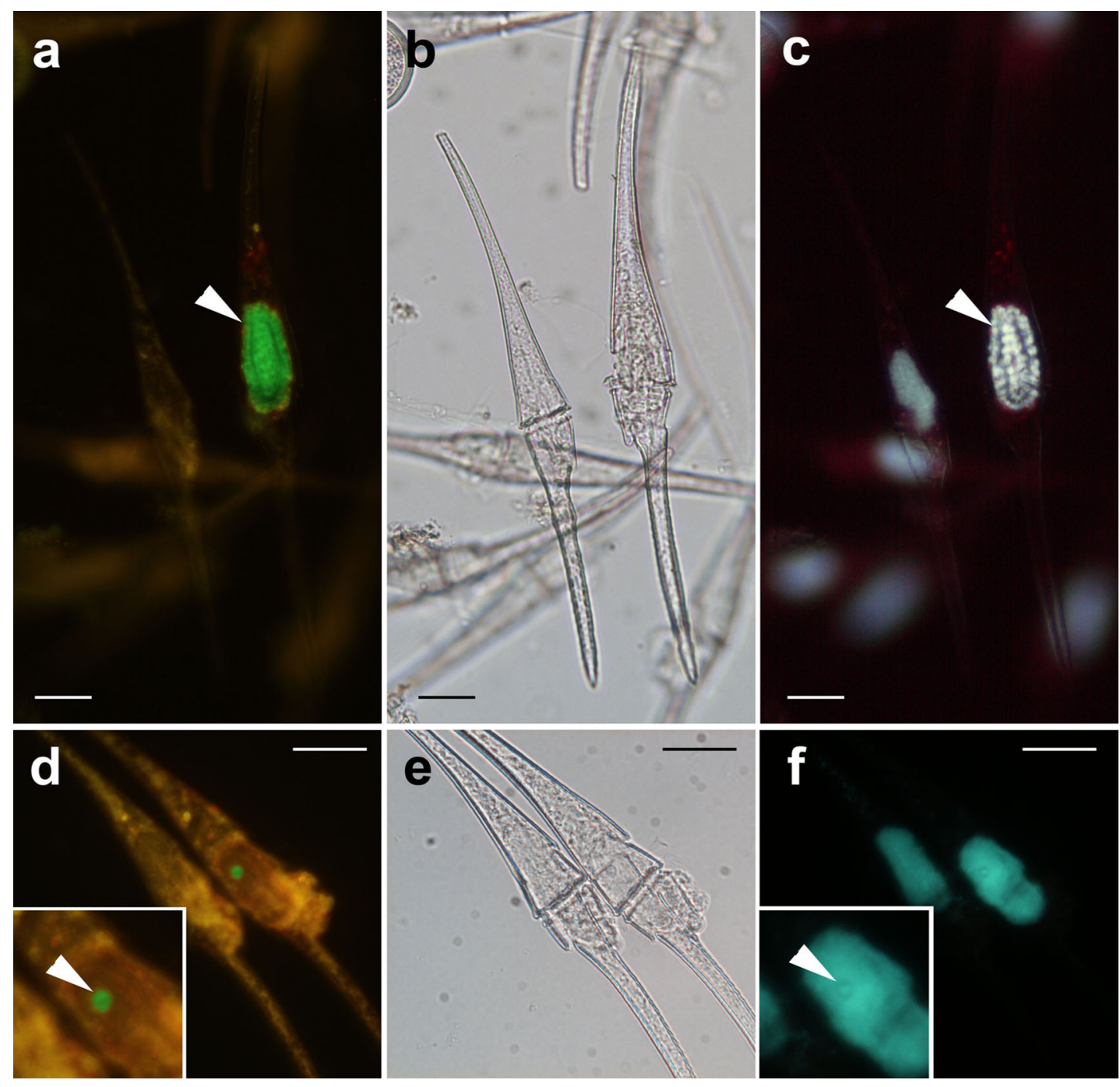

Fig. 5. Ceratium falcatiforme infected by Amoebophrya spp. (a-c) Late infection stage showing a mature parasitic trophont (arrowheads) occupying a large portion of the host's intracellular space; several non-infected cells are also seen (compare panels $\mathrm{a}$ and $\mathrm{b}$ ). The multinucleated pattern characteristic of Amoebophrya spp. is evident in panel c (arrowhead). (d-f) Early infection stage showing a ca. $5 \mu \mathrm{m}$ parasitoid (arrowheads) attached to the host's nucleus; a non-infected cell is also shown. The parasitoid location appears as a hollow space in the host's nucleus (f, arrowhead). Micrographs in each row represent the same specimens observed with different microscopic techniques. Left panels: epifluorescence microscopy unveiling the probe's signal (fluorescein dye); center panels: bright field microscopy; right panels: epifluorescence microscopy unveiling the DAPI signal. Scale bar $=20 \mu \mathrm{m}$
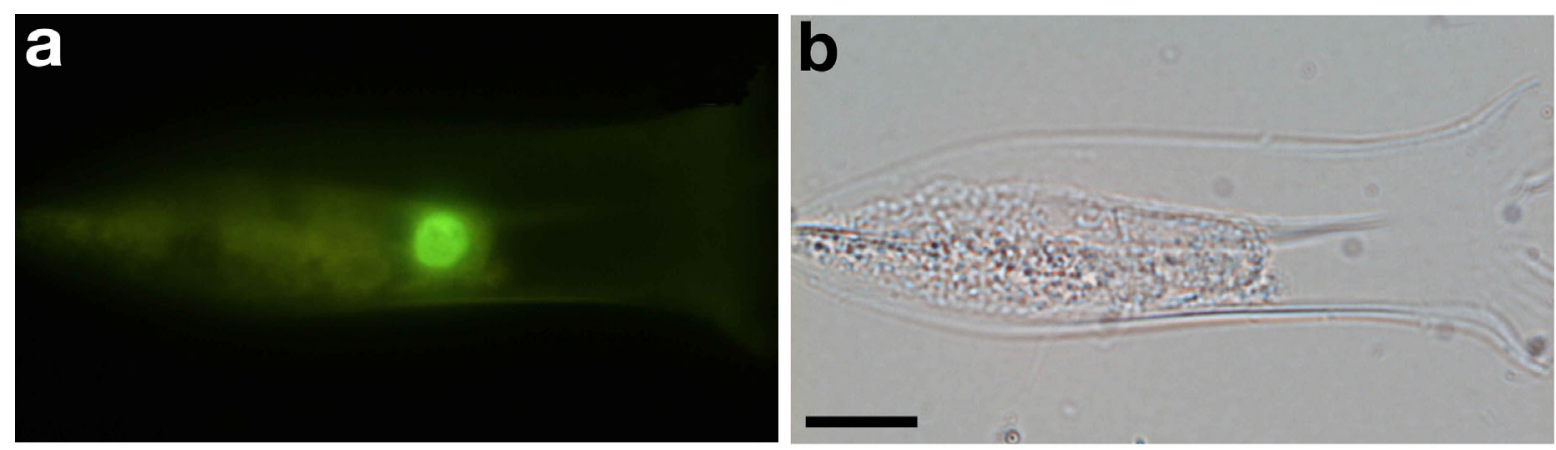

Fig. 6. A positive probe signal in a tintinnid ciliate. (a) Round body unveiled under epifluorescence microcopy with a filter set for fluorescein; (b) the same specimen as seen under bright-field microscopy. Scale bar $=20 \mu \mathrm{m}$ 
on cell biovolume was $46 \%$ higher in infected hosts (average $4144 \mathrm{pg} \mathrm{C}$ cell $^{-1}, \mathrm{CV}=17 \%$ ) compared to uninfected host cells (average $2827 \mathrm{pg} \mathrm{C} \mathrm{cell}^{-1}$, $\mathrm{CV}=14 \%$ ). Mature trophont biovolume averaged $12062 \mu^{3}$ (CV $\left.=19 \%\right)$. The estimated carbon content was $1670 \mathrm{pg} \mathrm{C}$ trophont $^{-1}$, which corresponds on average to $41 \%$ of the carbon in an infected cell.

\section{DISCUSSION}

In the present study, we successfully used an rRNAbased FISH assay to detect and quantify infection by the parasitoid dinoflagellate Amoebophrya spp. on photosynthetic and heterotrophic dinoflagellates in a tropical coastal area of the southern Atlantic Ocean. Our results, together with those of a previous study (Salomon et al. 2006b), indicate that infection of dinoflagellate populations by Amoebophrya might be a common phenomenon in this area.

Records on the infection of free-living dinoflagellate species by the parasitoid Amoebophrya spp. have accumulated since early reports at the end of the 19th century (see review by Park et al. 2004). The first and hitherto only report on the occurrence of Amoebophrya spp. in southern Atlantic coastal waters comes from the same area as the present study where cells of Protoperidinium spp. were found infected (Salomon et al. 2006b). The present study, besides expanding the knowledge on the distribution and importance of Amoebophrya spp. in tropical waters, constitutes the first account of infection of Ceratium falcatiforme by such parasitoids. Several other Ceratium species, including C. fusus, which is morphologically similar to C. falcatiforme, are among the dinoflagellate species reported to be infected by these parasitoids (Elbrächter 1973, Nishitani et al. 1985, Park et al. 2004 and references therein).

DNA sequencing of marine microbial communities from both northern and southern hemispheres, including coastal and oceanic areas, systematically retrieves eukaryote rDNA gene sequences similar to Amoebophrya spp. (López-García et al. 2001, Romari \& Vaulot 2004). Although Amoeborhya has not been reported to infect dinoflagellates in freshwater, similar rDNA sequences were recently found in a lake (Lepere et al. 2008). These findings have led to speculation on whether the actual distribution and abundance of Amoebophrya spp. parasitoids could be much larger than what is known based on observations of infected hosts. Nonetheless, while DNA sequencing of whole microbial communities is enlightening, in that it helps to unveil the diversity of marine eukaryotes, the alleged parasitic nature of some of these small eukaryotes from which the DNA sequences originate would be confirmed if they were actually found infecting potential hosts in nature. In this sense, FISH probes applied to whole-cell assays, like the one used in the present work, are one of the most suitable tools (Salomon et al. 2003a, Chambouvet et al. 2008).

Because the probe used in the present study was not designed to be specific for 1 single Amoebophrya sp., we cannot yet conclude whether there was only 1 Amoebophrya parasitoid with a broad host range or several different parasitoids with narrow host ranges (or a combination of both) infecting the various dinoflagellate species we observed. However, given the genetic diversity recently reported in Amoebophrya spp. originating from different dinoflagellate hosts (Gunderson et al. 2002, Salomon et al. 2003a, Chambouvet et al. 2008, Kim et al. 2008), the presence of multiple species/strains is a likely hypothesis. Confirmation on the genetic diversity of Amoebophrya spp. infecting different dinoflagellates in the Cabo Frio area must await DNA sequencing or the use of FISH probes designed towards genetically distinct parasitoids. In the present study, the probe's wide target range (within Amoebophrya spp.) assured that the maximum number of infected host species were recorded, giving a more complete picture of Amoebophrya spp. infection within the dinoflagellate populations present during our sampling. The probe specificity/range was tested in our study as we hybridized it against the natural communities containing a plethora of microorganisms, including several dinoflagellates. The effectiveness of the probe was confirmed by the fact the all parasitoid stages unmistakably identified by the DAPI signal, i.e. medium to mature multinucleated trophonts, as well as other features like hollow spaces in the host nucleus (see Fig. 5) or small round bodies in the host cytoplasm that are indicative of Amoebophrya infections (Salomon et al. 2003b, 2006a), were positively stained by the probe. Moreover, the fact that the probe did not stain any other cells in the samples reflects its degree of specificity towards Amoebophrya spp.

Amoebophrya spp. infecting primarily athecate dinoflagellate hosts have been suggested to have a narrower host range compared to those that use thecate dinoflagellates as primary hosts (Coats \& Park 2002, Kim 2006). However, high specificity by Amoebophrya spp. infecting thecate hosts has been observed in the field (Chambouvet et al. 2008). In the present study, thecate forms dominated the dinoflagellate communities. Although up to 9 different thecate dinoflagellate species were found infected in a single sample, parasitoid prevalence indicates a strong preference towards the genus Ceratium. Dinophysis acuminata was detected during the entire sampling period, in some cases at cell densities similar to those of C. falcatiforme, but infection was always below the 
detection limit. On the other hand, cells of 3 Ceratium species (C. tripos, C. furca, and C. macroceros), which were present in very low numbers, were found infected at all stations sampled on March 24, as well as throughout the first 2 wk of the studies at Stn E (see Table 1). This pattern is in agreement with previous observations by, e.g., Nishitani et al. (1985), who found up to 8 dinoflagellate species infected by Amoebophrya spp. in Quartermaster Harbour, Washington, USA, with parasitoid prevalence differing among different host species.

Although Ceratium falcatiforme dominated the plankton community at the beginning of the sampling period, maximum cell densities at Stn E were not extremely high (maximum ca. $3.5 \times 10^{3}$ cells $\mathrm{l}^{-1}$ ). For infection to occur, contact between free-living parasitoid stages (dinospores) and host cells is necessary, and the encounter rate is dependent on both host and free-living parasitoid cell densities. High Amoebophrya spp. prevalence in natural dinoflagellate populations is usually observed when host cell densities are on the order of $10^{6} \mathrm{l}^{-1}$ (e.g. Nishitani et al. 1985, Coats et al. 1996). It is possible that the C. falcatiforme cell densities during our sampling were not high enough to allow prevalence to escalate above the observed $7 \%$ of Amoebophrya spp. Reproductive output (i.e. number of dinospores produced per infected host cell) and dinospore success in establishing new infections are negatively affected when the hosts are grown in nutrient-limiting conditions, retarding parasitoid epidemics throughout the population (Yih \& Coats 2000). Cells in the decaying C. falcatiforme population were probably nutrient limited, which might have reduced parasitoid reproductive output. Moreover, grazing of Amoebophrya spp. free-living dinospores by ciliates takes place in nature and has been shown to strongly suppress infection (Maranda 2001, Johansson \& Coats 2002). The presence of tintinnids with a positive probe signal during our sampling strongly suggests such a trophic link, i.e. the ingestion of dinospores. The fact that a probe signal was only sporadically found in tintinnids is probably due to fast digestion of dinospores after ingestion.

The relatively large trophonts sporadically observed inside tintinnids might represent successful initial infection by Amoebophrya, either by the same strain/species infecting dinoflagellates or by another one more specific to tintinnids. Cachon (1964) described one Amoebophrya species, Amoebophrya tintinni, infecting the tintinnid Xystonella lohmanni. We cannot rule out the possibility that the FISH probe used in the present study hybridizes to other parasitoids closely related to the Amoebophrya spp. infecting dinoflagellates. Gene sequences from such parasitoids are needed to clarify their identity.
Similar to our observations of Ceratium falcatiforme, enlargement of dinoflagellate host cells upon infection by Amoebophrya spp. has also previously been reported (Taylor 1968, Kim et al. 2004, Chambouvet et al. 2008). This has been interpreted to reflect the maintenance of photosynthetic activity by the host during Amoebophrya spp. maturation and the simultaneous parasitoid assimilation of host photosynthetic products for growth (Park et al. 2004).

An important aspect of the infection of natural dinoflagellates by Amoebophrya spp. is the extent to which parasitism contributes as a loss factor for host populations. Significant Amoebophrya-induced mortality has been reported in, e.g., Gyrodinium uncatenum and Gonyaulax catenella populations when prevalence levels were as high as 81 and $30 \%$, respectively (Nishitani et al. 1985, Coats et al. 1996). Our data showing the concurrent decline in Ceratium falcatiforme cell numbers and increase in parasitoid prevalence suggest some influence of parasitism. Moreover, the temporal pattern in the percentage of late infection stages indicates a more-or-less synchronized wave of infection throughout the host population. If the generation time of the parasitoid inside the host is known, the fraction of cells in a given host population killed per day can be estimated by dividing prevalence by the generation time of the parasitoids (Coats \& Bockstahler 1994). The generation time for the Amoebophrya-C. falcariforme system has not been estimated, but existing data from other cultured Amoebophrya-dinoflagellate systems show development times ranging from 1.4 to $3 \mathrm{~d}$ at $20^{\circ} \mathrm{C}$ (Coats \& Park 2002). High temperature, as observed during our sampling occasions, is expected to speed up parasitoid growth, thus shortening development time. Assuming that there was a linear increase in parasitoid prevalence from 0.9 to $6.7 \%$ during the first week of our sampling period and an intracellular generation time of $2 \mathrm{~d}$ for the parasitoid (which is reasonable considering the in situ water temperature), Amoebophrya would have killed ca. $11 \%$ of the host cell population within this $6 \mathrm{~d}$ period. The actual decrease in C. falcatiforme cell densities for that period was ca. $94 \%$ (from

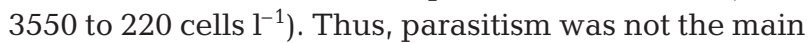
factor behind the $C$. falcatiforme population decline during our survey, though it likely accelerated the process. From the above estimates, it becomes evident that loss factors other than parasitism by Amoebophrya spp. contributed to the decline in C. falcatiforme between March 24 and March 30. Sampling Stn E is situated in a protected area inside Anjos Bay. Furthermore, water temperature suggests we were sampling in the same water mass over the entire period. Therefore, losses due to advection were probably not very high. Copepods were in very low abundance in the net 
tows from the location where the dinoflagellates were collected, indicating that grazing was not a relevant loss factor either, even if the copepods in the area would have been able to graze on such large $C$. falcatifome cells. The increase in numbers of low-pigmented cells and intact, empty C. falcatiforme theca during the sampling period suggests that the cells were metabolically damaged and were dying. Exhaustion of nutrients, which are usually scarce in the area during downwelling conditions (Valentin 1984), was probably the main cause for the $C$. falcatiforme population decline.

The $94 \%$ decrease in Ceratium falcatiforme cell numbers between March 24 and March 31, including the $11 \%$ killed by Amoebophrya spp., corresponds to

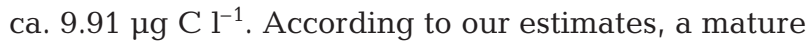
trophont, which differentiates into dinospores shortly after emergence from its host, accounts for $41 \%$ of the carbon in an infected C. falcatiforme cell. Such a value is in line with results from Yih \& Coats (2000), who estimated, based on number and size of dinospores produced per host, that Amoebophrya sp. infecting Gymnodinium sanguineum (=Akashiwo sanguinea) converts between 31 and $48 \%$ of its host's biomass into parasitoid biomass, depending on the host's nutritional status. Assuming all infections observed in the C. falcatiforme population during our survey reached maturation and produced dinospores, host biomass transformed into Amoebophrya dinospore biomass during the above-mentioned decline amounts to ca. $0.64 \mu \mathrm{g} \mathrm{C}$ $\mathrm{l}^{-1}$, or $6.5 \%$ of the total value. In other words, $6.5 \%$ of the carbon previously in the form of C. falcatiforme cells, which would otherwise be lost as dissolved organic material or cell debris upon cell death, was instead transformed into parasitoid dinospores. These dinospores were then available to microzooplankton, potentially creating a new trophic link. The magnitude of such a link would depend on the microzooplankton grazing potential, and its duration is probably short, since Amoebophrya spp. dinospores only survive for hours to days when hosts are absent (Coats \& Park 2002).

Oceanographic conditions during our survey are typical of a downwelling state. During such periods, oligotrophic waters dominate in the Cabo Frio area and the plankton community experiences extensive nutrient limitation (Valentin 1984). The system is then characterized by a microbial food web structure, whereby carbon produced by bacteria and small phytoplankton cells is channeled via flagellates and ciliates up to the mesozooplankton and higher trophic levels (Guenther et al. 2008). Occasional development of large dinoflagellate cells-like Ceratium falcatiforme-during these periods might restrict carbon flow up the food web. The temporary trophic link created by the pres- ence of Amoebophrya spp. dinospores would then be important in such cases, since it retains part of the carbon that would otherwise be lost to deep layers upon host population decline. Infection of large host cells is expected to make such a process relevant even at relatively low parasitoid prevalence levels, because parasitoid biomass produced per host is higher relative to the biomass of small hosts. The importance of parasitism on dinoflagellate populations in oligotrophic coastal areas might generally be underestimated.

Acknowledgements. We thank L. R. Gaelzer, C. E. L. Ferreira, and the crew of the RV 'Diadorim' (IEAPM, Arraial do Cabo, Brazil) for sampling assistance, M. C. Q. Mendes and S. C. Viana (UFRJ, Rio de Janeiro, Brazil) for their help with Ceratium identification, and C. Esplund (University of Kalmar) for laboratory assistance with FISH assays. The study was financially supported by the Swedish National Research Council (VR), Swedish Research Council for Environment, Agricultural Sciences and Spatial Planning (FORMAS), the European community through the project MIDTAL (Microarrays for The Detection of Toxic Algae), FP7-2007, Environment (Including Climate Change), Sub-Priority 6.3.3.1 contract holder Edna Granéli, and the Vice-Chancellor Strategic Fund, University of Kalmar, contract holder Paulo Salomon.

\section{LITERATURE CITED}

Cachon J (1964) Contribuition à l'étude des Péridiniens parasites. Cytologie, cycles évolutifs. Ann Sci Nat B 6:1-158

Cachon J, Cachon M (1987) Parasitic dinoflagellates. In: Taylor FJR (ed) The biology of dinoflagellates. Blackwell Scientific Publications, Oxford, p 571-610

> Chambouvet A, Morin P, Marie D, Guillou L (2008) Control of toxic marine dinoflagellate blooms by serial parasitic killers. Science 322:1254-1257

> Coats DW, Bockstahler KR (1994) Occurrence of the parasitic dinoflagellate Amoebophrya ceratii in Chesapeake Bay populations of Gymnodinium sanguineum. J Eukaryot Microbiol 41:586-593

> Coats DW, Park MG (2002) Parasitism of photosynthetic dinoflagellates by three strains of Amoebophrya (Dinophyta): parasite survival, infectivity, generation time, and host specificity. J Phycol 38:520-528

Coats DW, Adam EJ, Gallegos CL, Hedrick S (1996) Parasitism of photosynthetic dinoflagellates in a shallow subestuary of Chesapeake Bay, USA. Aquat Microb Ecol 11:1-9

Combes C (2001) Parasitism: the ecology and evolution of intimate interactions. The University of Chicago Press, Chicago

Elbrächter M (1973) Population dynamics of Ceratium in coastal waters of the Kiel Bay. Oikos 15(Suppl):43-48

Gisselson LÅ, Carlsson P, Granéli E, Pallon J (2002) Dinophysis blooms in the deep euphotic zone of the Baltic Sea: Do they grow in the dark? Harmful Algae 1:401-418

> Guenther M, Gonzalez-Rodriguez E, Carvalho WF, Rezende CE, Mugrabe G, Valentin JL (2008) Plankton trophic structure and particulate organic carbon production during a coastal downwelling-upwelling cycle. Mar Ecol Prog Ser 363:109-119

Gunderson JH, John SA, Boman C II, Coats DW (2002) Multiple strains of the parasitic dinoflagellate Amoebophrya 
exist in Chesapeake Bay. J Eukaryot Microbiol 49: 469-474

Hillebrand H, Durselen CD, Kirschtel D, Pollingher U, Zohary $\mathrm{T}$ (1999) Biovolume calculation for pelagic and benthic microalgae. J Phycol 35:403-424

Ibelings BW, De Bruin A, Kagami M, Rijkeboer M, Brehm M, van Donk E (2004) Host parasite interactions between freshwater phytoplankton and chytrid fungi (Chytridiomycota). J Phycol 40:437-453

Johansson M, Coats DW (2002) Ciliate grazing on the parasite Amoebophrya sp. decreases infection of the red-tide dinoflagellate Akashiwo sanguinea. Aquat Microb Ecol 28:69-78

Kim S (2006) Patterns in host range for two strains of Amoebophrya (Dinophyta) infecting thecate dinoflagellates: Amoebophyra spp. ex Alexandrium affine and ex Gonyaulax polygramma. J Phycol 42:1170-1173

Kim S, Park MG, Yih W, Coats DW (2004) Infection of the bloom-forming thecate dinoflagellates Alexandrium affine and Gonyaulax spinifera by two strains of Amoebophrya (Dinophyta). J Phycol 40:815-822

Kim S, Park MG, Kim KY, Kim CH, Yih W, Park JS, Coats DW (2008) Genetic diversity of parasitic dinoflagellates in the genus Amoebophrya and its relationship to parasite biology and biogeography. J Eukaryot Microbiol 55:1-8

Lepere C, Domaizon I, Debroas D (2008) Unexpected importance of potential parasites in the composition of the freshwater small-eukaryote community. Appl Environ Microbiol 74:2940-2949

López-García P, Rodríguez-Valera F, Pedrós-Alió C, Moreira D (2001) Unexpected diversity of small eukaryotes in deep-sea Antarctic plankton. Nature 409:603-607

Maranda L (2001) Infection of Prorocentrum minimum (Dinophyceae) by the parasite Amoebophrya sp. (Dinoflagellea). J Phycol 37:245-248

Menden-Deuer S, Lessard EJ (2000) Carbon to volume relationships for dinoflagellates, diatoms, and other protist plankton. Limnol Oceanogr 45:569-579

Nishitani L, Erickson G, Chew KK (1985) Role of the parasitic dinoflagellate Amoebophrya ceratii in control of

Editorial responsibility: Patricia Glibert,

Cambridge, Maryland, USA
Gonyaulax catenella populations. In: Anderson DM, White AW, Baden DG (eds) Toxic dinoflagellates. Elsevier, New York, p 225-230

Park MG, Cooney SK, Yih W, Coats DW (2002) Effects of two strains of the parasitic dinoflagellate Amoebophrya on growth, photosynthesis, light absorption, and quantum yield of bloom-forming dinoflagellates. Mar Ecol Prog Ser 227:281-292

> Park MG, Yih W, Coats DW (2004) Parasites and phytoplankton, with special emphasis on dinoflagellate infections. J Eukaryot Microbiol 51:145-155

Romari K, Vaulot D (2004) Composition and temporal variability of picoeukaryote communities at a coastal site of the English Channel from 18S rDNA sequences. Limnol Oceanogr 49:784-798

Salomon PS, Janson S, Granéli E (2003a) Multiple species of the dinophagous dinoflagellate genus Amoebophrya infect the same host species. Environ Microbiol 5: 1046-1052

Salomon PS, Janson S, Granéli E (2003b) Parasitism of Dinophysis norvegica by Amoebophrya sp. in the Baltic Sea. Aquat Microb Ecol 33:163-172

Salomon PS, Janson S, Gisselson LÅ, Granéli E (2006a) Analytical detection of parasite infection of Dinophysis norvegica using FISH probes. Afr J Mar Sci 28:353-355

Salomon PS, Rodriguez EG, Granéli E (2006b) First report of Amoebophrya sp. parasites infecting dinoflagellates from Brazilian coastal waters. J Coast Res Spec Issue 39:1090-1093

Taylor FJR (1968) Parasitism of the toxin-producing dinoflagellate Gonyaulax catenella by the endoparasitic dinoflagellate Amoebophrya ceratii. J Fish Res Board Can 25: 2241-2245

Utermöhl H (1958) Zur Vervollkommung der quantitativen Phytoplankton-Methodik. Mitt Int Ver Limnol 9:1-38

Valentin JL (1984) Analysis of hydrobiological parameters in the Cabo Frio (Brazil) upwelling. Mar Biol 82:259-276

Yih W, Coats W (2000) Infection of Gymnodinium sanguineum by the dinoflagellate Amoebophrya sp.: effect of nutrient environment on parasite generation time, reproduction, and infectivity. J Eukaryot Microbiol 47:504-510

Submitted: December 13, 2008; Accepted: February 19, 2009 Proofs received from author(s): April 16, 2009 